\title{
Vagrant species of birds captured at Durankulak ringing camp, NE Bulgaria, 2019-2020
}

\author{
Peter Shurulinkov ${ }^{1}$, Patrick Bergkamp ${ }^{2}$, Nikola Aleksandrov ${ }^{3}$, Pavel Simeonov ${ }^{4}$, Andrey \\ Ralev $^{5}$, Petko Tsvetkov ${ }^{6}$, Konstantin Popov ${ }^{7}$, Girgina Daskalova ${ }^{1}$, Katherine Dimitrova ${ }^{1}$, \\ Krassimir Hristov ${ }^{5}$, Ivan Hristov ${ }^{8}$, Jivko Gradinarov ${ }^{9}$, Ivaylo Tonev ${ }^{10}$, Boris Hotinov ${ }^{11}$, \\ Dimitar A. Dimitrov ${ }^{12}$, Meinolf Ottensman ${ }^{13}$, Tony Rinaud ${ }^{13}$, Nayden Chakarov ${ }^{13}$
}

(1) National Museum of Natural History, Bulgarian Academy of Sciences, 1 Tsar Osvoboditel Blvd, 1000 Sofia, Bulgaria, p.shurulinkov@gmail.com; https://orcid.org/0000-0002-6586-8690

(2) Havikshorst 12,1083TT Amsterdam, The Netherlands, pybergkamp@hotmail.com

(3) 11 Bozhko Ivanov Street, 3900 Belogradchik, Bulgaria, ndaleksandrov@gmail.com

(4) Foundation "Le Balkan - Bulgaria", Branta Birding Lodge and Conservation Centre, 9670 Durankulak, Bulgaria, lebalkan@lebalkan.org

(5) Balkani Wildlife Society, 8 Dragan Tzankov Blvd, 1164 Sofia, Bulgaria, alibotush@gmail.com

(6) Bulgarian Biodiversity Foundation, 6 Triaditsa, Flat 5, 504, 1000 Sofia, Bulgaria, petko.tzvetkov@gmail.com

(7) One Nature Society, Burgas, Bulgaria, office@onenat.org

(8) WWF-Bulgaria, 19B Tsar Boris III, Flat 4-5, 1612 Sofia, Bulgaria, ihristov2015@gmail.com

(9) 6 Prof. Nikolay Genchev, Sofia, Bulgaria, nolldor@gmail.com

(10) 18 Vardar Street, Nadezhda 2, Sofia, Bulgaria, ivaylo.tonev@gmail.com

(11) SRTI - Bulgarian Academy of Sciences, 1 Georgi Bonchev Street, Block 1, 1113 Sofia, Bulgaria, bmh@space.bas.bg

(12) Green Balkans - Plovdiv, Skopie Street, 4000 Plovdiv, Bulgaria, office@greenbalkans.org

(13) Department of Animal Behaviour, Bielefeld University, 33501 Bielefeld, Germany, az.nayden@gmail.com

\begin{abstract}
The area of Coastal Dobrudzha in NE Bulgaria is well known for its richness of vagrants. A long-term research project was started at a location at Durankulak Lake, on the northern Black Sea Coast, aiming to obtain data on the characteristics of autumn migration of passerine birds and on the presence of vagrants there. A total of 20 mist nets with an overall length of 200 meters were set between August and October in two different habitats - reed bed and broad-leaved forest. In 2019, a total of 9344 birds of 84 species were caught and ringed. In 2020, the number of the birds caught increased to 13786 of 93 species. Vagrants such as dusky warbler (Phylloscopus fuscatus), yellow-browed warbler (Phylloscopus inornatus) and red-flanked bluetail (Tarsiger cyanurus) were captured in 2020. Detailed information about these findings is given in the present work.
\end{abstract}

Keywords: bird migration, Durankulak Lake, dusky warbler, red-flanked bluetail, yellow-browed warbler, vagrants

\section{Introduction}

Autumn passerine migration is not systematically studied along the northern part of the Bulgarian Black Sea Coast. The area of maritime Dobrudzha is well known for its richness of vagrants and rare birds of different orders having eastern or northern origin like Phala- ropus fulicarius, Charadrius mongolus, Lanius isabellinus, Serinus pussilus, Phylloscopus proregulus and many others (Dontschev, 1967; Mitev \& Welsch, 2011; Simeonov, 2013; Ignatov et al., 2015; Simeonov, 2015). Along the North Bulgarian Black Sea Coast, records of vagrants are mostly a result of intensive field monitoring. Until 2019, ringing activities had occa- 
sional and sporadic character. There is no functioning ringing station in the coastal part of NE Bulgaria. Until now, occasional short term ringing activities, mostly during summer and autumn, had been carried out at Durankulak Lake and Shabla Tuzla Lake (Dimitrov et al., 2018; own unpublished data).

In Romania, two field ringing stations have operated in recent years on the Black Sea Coast - Chituc (Razelm - Sinoe Lake complex) and Agigea (Marton, 2020; Agigea Ringing Station, Facebook) and a spring ringing camp at the Danube Delta (danubebirdringing). All these studies showed that the area attracts a high number of vagrant species of birds. Captures of species such as yellow-browed warbler (Phylloscopus inornatus), greenish warbler (Phylloscopus trochiloides), Pallas's leaf warbler (Phylloscopus proregulus), dusky warbler (Phylloscopus fuscatus), green warbler (Phylloscopus nitidus), red-flanked bluetail (Tarsiger cyanurus), Asian desert warbler (Sylvia nana), rustic bunting (Emberiza rustica) and others were recently reported from the Romanian stations (Marton, 2020).

Thus we decided to start a long-term research at a study point at Durankulak Lake, NE Bulgaria, on the Black Sea Coast. The aim was to study the characteristics of autumn migration of passerine birds, and to obtain data about the presence of vagrants on Bulgarian territory. We expected that some of those species recorded in Romania might also be captured in our ringing camp, which would be a valuable contribution to the knowledge of the avifauna of Bulgaria. In August - October of 2019 and 2020, we organised large-scale autumn ringing campaigns at Durankulak Lake ringing camp.

The ringing activities at Durankulak Lake are also valuable for the education of students and volunteers. Across both years, 45 and 80 experts and volunteers, respectively, took part in the ringing camp.

\section{Materials and methods}

The ringing camp was situated at the south-eastern part of the Durankulak Lake, Dobrich Province, NE Bulgaria, at coordinates $43^{\circ} 39^{\prime} 38.49 \mathrm{~N}$ and $28^{\circ} 33^{\prime} 56.81 \mathrm{E}$. A total of 20 mist nets with an overall length of 200 meters were set in two separate lines, covering two different habitats. Nine to ten nets $(100 \mathrm{~m})$ were set in a reed bed along a dyke dividing a shallow south-eastern bay of the lake from the main lake. Ten nets $(100 \mathrm{~m})$ were set in low mixed broad-leaved forest with bushes,

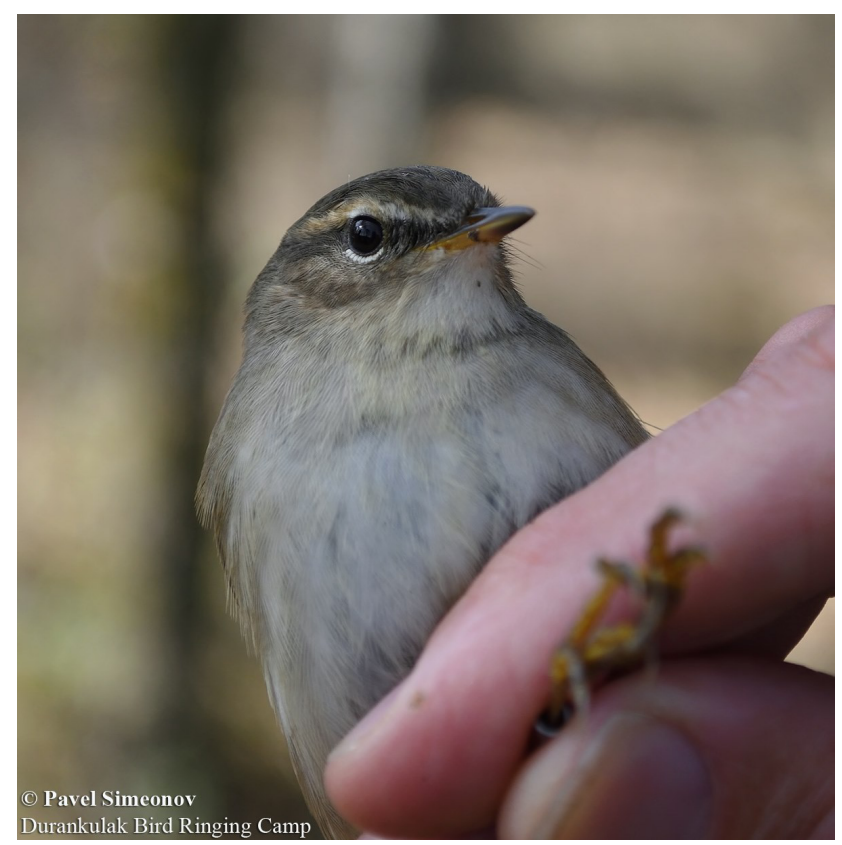

Fig. 1. Dusky warbler (Phylloscopus fuscatus), 5.10.2020, Durankulak Lake (Photo: Pavel Simeonov)

close to the sea shore. The forest was dominated by $U l-$ mus sp., Fraxinus sp., Robinia pseudoacacia and other low trees. The distance between the two lines of nets was approximately $700 \mathrm{~m}$.

The period of the study in 2019 was between 24 August and 15 October. In 2020 the study expanded in time covering the period 15 August -1 November. The position and number of the nets remained the same for both years.

Recordings of bird calls and songs were used to attract birds to the nets at both habitats. For each month collections of sounds of different species were used in the forest and in the reeds. The species were chosen taking into account the prevailing migrant composition for the particular month and habitat according to the available literature sources for other locations from the Balkan Peninsula (Nankinov, 2009; Ivanov, 2011; Marton, 2020) and our own data.

\section{Results and discussion}

In 2019, a total of 9344 birds of 84 species (including recaptures) were caught and ringed at Durankulak ringing camp. In 2020, the numbers of birds caught increased to 13786 of 93 species. The following vagrant birds were captured: 


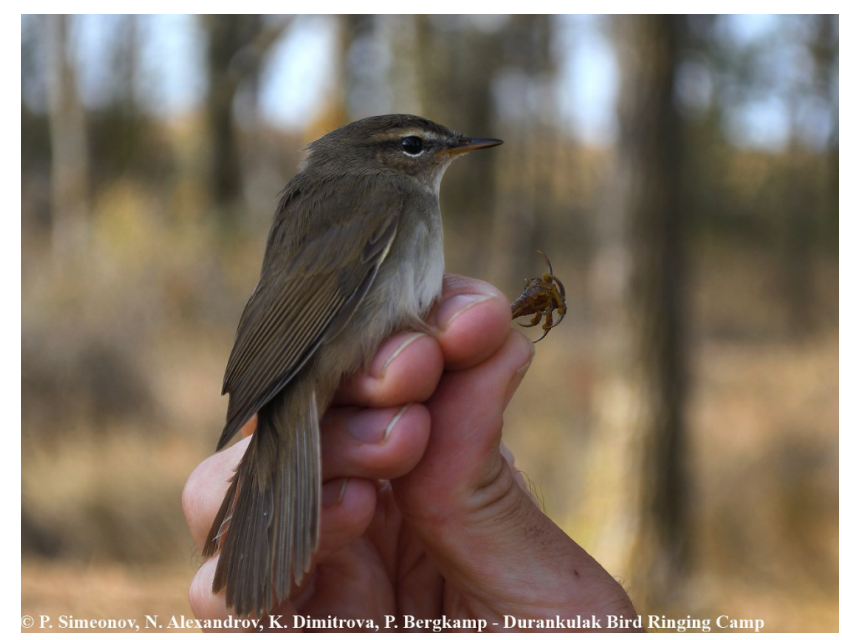

Fig. 2. Dusky warbler (Phylloscopus fuscatus), 5.10.2020, Durankulak Lake (Photo: Pavel Simeonov)

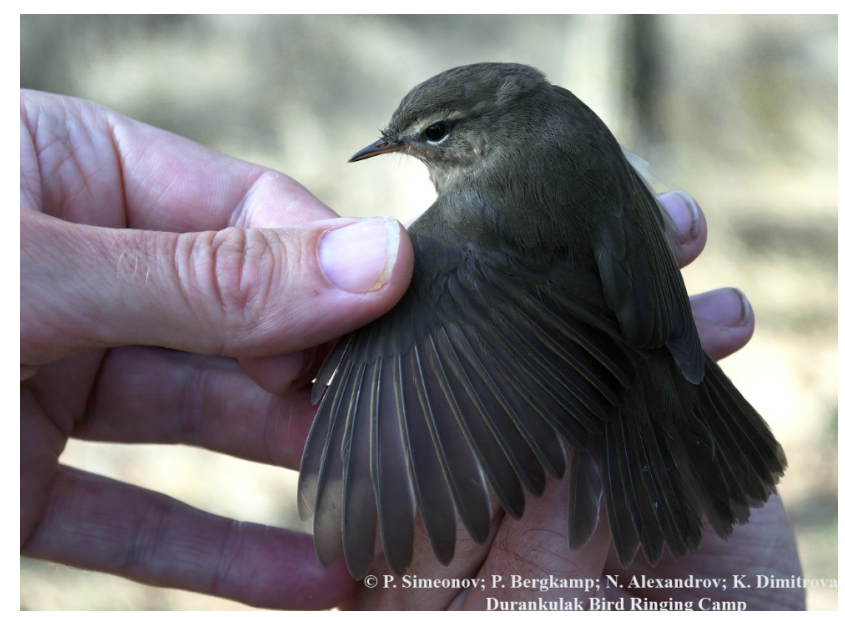

Fig. 3. Dusky warbler (Phylloscopus fuscatus), 5.10.2020, Durankulak Lake (Photo: Pavel Simeonov)

\section{Dusky warbler (Phylloscopus fuscatus)}

One 1st year dusky warbler was caught on the morning of 05.10.2020 in the forest line of nets (Figs 1-3).

Description: Small warbler, generally brown in colour. Obvious dark eye stripe and whitish supercilium. Supercilium quite short, not extending to the nape. Legs dark brown and long. Toes yellowish from below. Breast and belly are greyish-white. Weak, unclear dark throat band. Fine bill, dark with yellowish base of lower mandible. Tail quite long, with great distance between central and outer tail feathers.

Wing formula: First primary very long, much longer than primary coverts. Tip of the wing formed by the fourth primary. Outer emarginations presented on $3,4,5,6$ primaries. The line from the tip of the 2 nd primary equals the tip of the 8 th primary.

Measurements: Wing length $-61.5 \mathrm{~mm}$; bill depth $-2.4 \mathrm{~mm}$; bill width $-3.1 \mathrm{~mm}$; tarsometatarsus -24.6 $\mathrm{mm}$; tail $-39 \mathrm{~mm}$; weight $-8.9 \mathrm{~g}$; fat score -1 .

Discussion: This species is new for the Bulgarian ornithofauna (Ivanov et al., 2009; Ivanov et al., 2015). Its breeding range is situated in Central and Eastern Siberia, NE Kazakhstan, Northern and Eastern China and North Korea (Cramp et al., 1992). It is a migratory species wintering normally in Southern China, Thailand, Burma, India, Nepal (Cramp et al., 1992). Rare vagrant to Europe - it is observed or captured in Great Britain, Ireland, France, Spain, Poland, Austria, Italy, Estonia, Cyprus, Greece, Albania, etc. (Cramp et al.1992; Handrinos \& Akriotis, 1997; Albanian Ornithological Society, Facebook). In Romania, two specimens have been caught and ringed on 2.10.2016 and 14.10.2016 at Chituc ringing station (Marton, 2020) and one more on 29.09.2008 at Sfintu George, Danube Delta (Martin \& Pochelon, 2008). Most of the records of the species in Central and Eastern Europe are between September and February (Bozo et al., 2016), and on the British Isles - between mid-October and mid-November (Harrop, 2007).

\section{Yellow-browed warbler (Phylloscopus inornatus)}

One adult yellow-browed warbler was caught on the morning of 06.10 .2020 in the reed line of nets (Figs 4-5).

Description: Very small warbler, with short tail and fine bill. Strong yellow supercillium. Long, clear black eye-stripe. It has two clear white wing-bars. Crown and back olive-greenish. Underparts whitish. Legs dark brown.

Wing formula: First primary longer than primary coverts. Tip of the wing formed by the third primary. Outer emarginations presented on 3, 4, 5 primaries. The line from the tip of the 2 nd primary equals the tip of the 6th primary.

Measurements: Wing length $-53 \mathrm{~mm}$, tarsometatarsus $-16.99 \mathrm{~mm}$; bill $-7.45 \mathrm{~mm}$, weight $-5.72 \mathrm{~g}$, fat score -2 .

Discussion: The species is a rare vagrant recorded at least five times in Bulgaria until now. According to Ivanov et al. (2021), it has been observed three times in Bulgaria until 2019. One bird was ringed on 


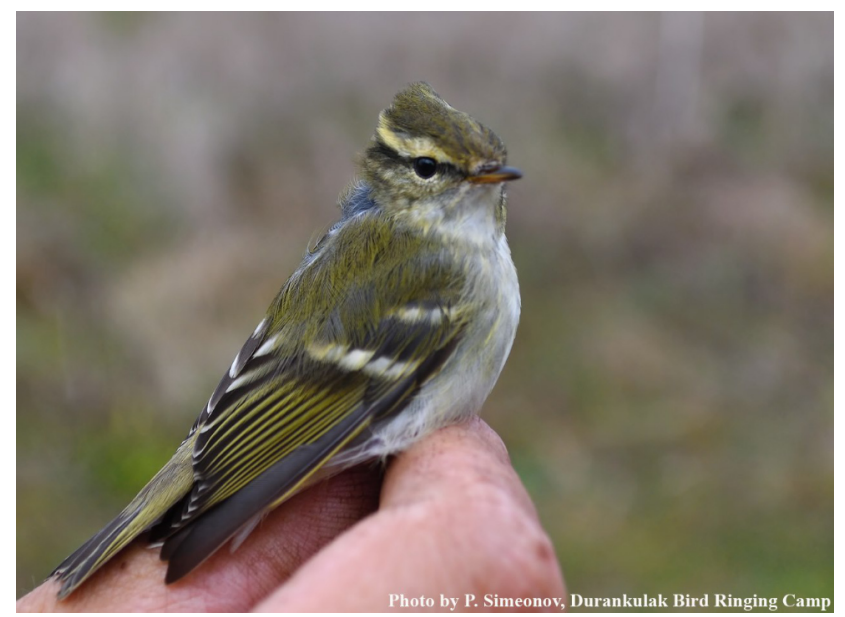

Fig. 4. Yellow-browned warbler (Phylloscopus inornatus), 6.10.2020, Durankulak Lake (Photo: Pavel Simeonov)

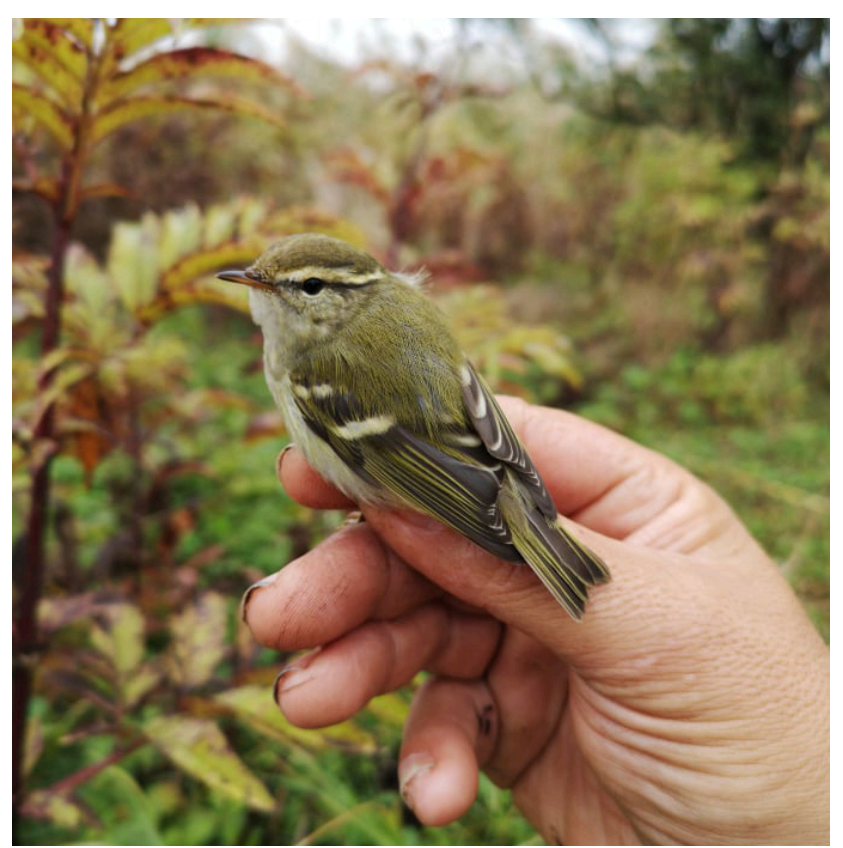

Fig. 5. Yellow-browned warbler (Phylloscopus inornatus), 6.10.2020, Durankulak Lake (Photo: Nikola Aleksandrov)

28.09.2005 at Atanasovsko Lake, close to Burgas (Nankinov et al. 2005). Another bird was observed few days later - on 2.10.2005 at Cape Kaliakra, Dobrich District. A third bird was seen and photographed again in October - on 14.10.2013 (locality not mentioned). Another two observations were not included as confirmed by Ivanov et al. (2021). The first observation of the species in Bulgaria was made on 27.09.1987 in Plovdiv (Kyuchukov, 1997). One day earlier to our finding, on 5.10.2020, one yellow-browed warbler was observed and photographed at Gorun Village, Dobrich District (Yanko Yankov, pers.comm.). That locality is situated $18.9 \mathrm{~km} \mathrm{SW}$ from Durankulak Lake ringing camp.

The species normally breeds from the NE parts of European Russia (including Ural Mts) to the Pacific Ocean Coast and in Mongolia, NE China and Japan. It overwinters in E India, SE China and the Malay Peninsula (Cramp et al., 1992, Keller et al., 2020). It is the most regular Siberian vagrant in Europe (Williamson, 1983). In some European countries (UK, Sweden, Netherlands, France), it is already considered as a "regular migrant" during autumn (Van den Berg \& Bosman, 1999; Reeber et al., 2008). In NW Europe, the records of the species are numerous and show a peak in September and October but become much scarcer in SW Europe (De Juana, 2008). The later study suggests the explanation that the majority of these birds reach only as far as NW Europe, do not continue to the Iberian Peninsula and Africa and migrate back directly to Asia. Similarly, records of the yellow-browed warbler are also scarce from the Balkan Peninsula. At Chituc ringing camp, Romania, a total of ten yellowbrowed warblers were captured during autumn migration over 6 years, 2014-2019 (Marton, 2020). In NE Europe, a slight shift of breeding range of the species towards the west was recorded (Keller et al., 2020). This can explain the high number of records of the species in $\mathrm{W}$ and $\mathrm{C}$ Europe during the recent decades.

\section{Red-flanked bluetail (Tarsiger cyanurus)}

One adult female red-flanked bluetail was captured in the forest nets of Durankulak ringing camp, on 24.10.2020 (Figs 6-7).

Description: Typical plumage of a female having blue tail and rump, orange flanks, white belly and breast, greenish-brown back, mantle and head. Bill and legs black, iris - dark brown.

Measurements: Wing length $-76 \mathrm{~mm}$, tarsometatarsus $-22.4 \mathrm{~mm}$, bill (to feathers) $-9.0 \mathrm{~mm}$, bill (to skull) $-13.0 \mathrm{~mm}$, tail $-53 \mathrm{~mm}$, weight $-11.6 \mathrm{~g}$, fat score -2 .

Discussion: Before the observation presented here the species had been recorded in Bulgaria on only in two occasions (Ivanov et al., 2021) and had never been captured or ringed. The first observation was made by Petar Iankov at Cape Emine (Burgas District) on 


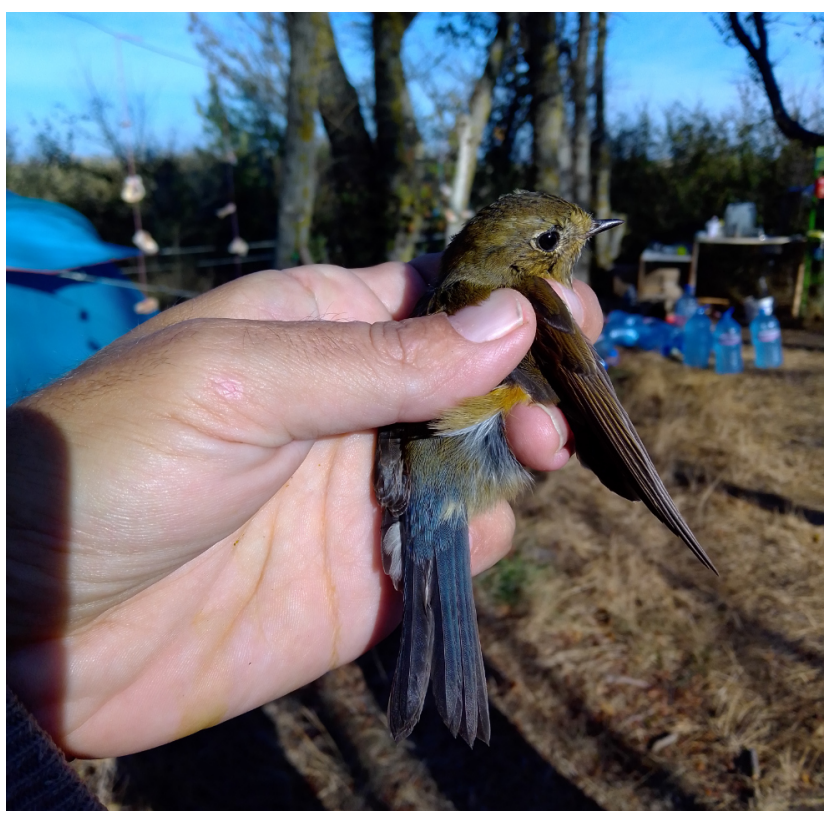

Fig. 6. Red-flanked bluetail, female (Tarsiger cyanurus), 24.10.2020, Durankulak Lake (Photo: Peter Shurulinkov)

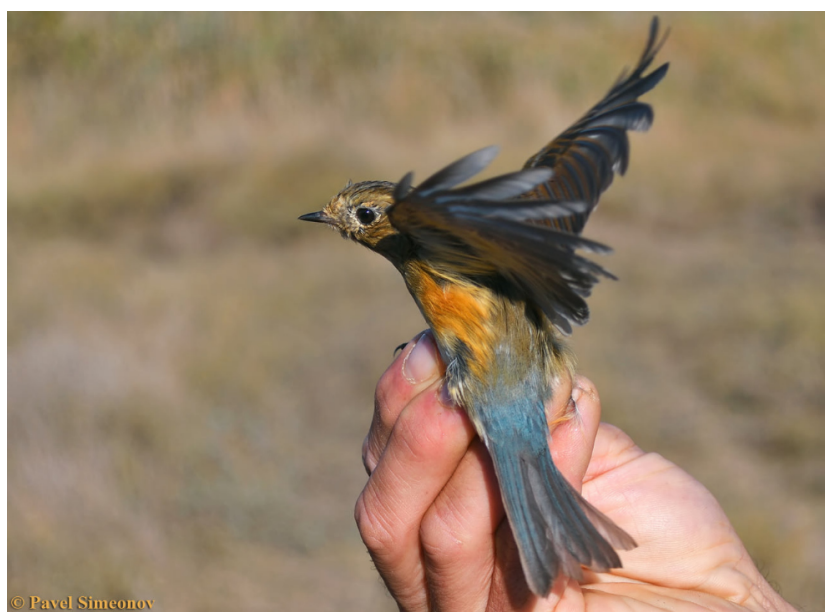

Fig. 7. Red-flanked bluetail, female (Tarsiger cyanurus), 24.10.2020, Durankulak Lake (Photo: Pavel Simeonov)

3.06.2000. The second observation (documented with photographs) was made by Chris Day in the town of Byala, Varna District, on 28.10.2018. In Romanian Dobrudzha, the species has been caught and ringed at Chituc Station - three specimens, one every autumn in the period 2017-2019 (Marton, 2020). Also one individual was captured at the Agigea Station, on 22.10.2020, only two days before the finding of the species at Durankulak Lake (Agigea Ringing Station, Facebook). During the same month the species was re- corded for the first time in Serbia as well - at Bajina Basta, Tara Mt (Medenica I., Facebook). We can conclude that, although very scarce, the red-flanked bluetail passes regularly through the Balkan Peninsula, mostly in October, and especially along the Black Sea Coast.

\section{Acknowledgements}

We want to thank to all the participants in the field work at Durankulak Lake ringing station and to the people who contributed to the organisation of the study: Georgi Dilovski, Miroslav Dravecky, Milan Olekšak, Teodor Trifonov, Mihail Iliev, Diana Simeonova, Rosena Tomova, Yana Yordanova, Marta Dimiitrova, Borislav Borisov, Hristo Dinkov, Svetoslav Velkov, Ivaylo Nikolov, Ana Doneva, Denitsa Lyubenova, Dimitar Z. Dimitrov, Boris Nikolov, Kaloyana Kosseva, Stefaniya Kamenova, StelaTeodora Trendafilova, Liliana Vassileva, Miroslava Popova, Vangel Vangelov, Kristin Meshinska, Irena Atanasova, Maria Dilovska, Elena Uzunova, Martin Martinov, Vera Staevska, Steve Mumford, Zhivko Dzhakov, Olya Dzhakova, Efrosina Hristova, Kalina Hristova, Victor Dzhakov, Stoyana Dzhakova, Elitsa Maximova, Ivan Ivanov, Maria Naumova, Kristiana Kaydzhieva, Irina Ivanova, Kristina Panova, Polina Temenlieva, Angel Hadzhijski, Zdravko Grigorov, Pavlina Michailova, Rumyana Boyanova, Dilyana Doynova, Danita Zarichinova, Ivailo Hlebarov, Anton Sokolov, Maya Slavova,Yana Lefterova, Elitsa Maximova, Rumyana Pankova,Yulia Yordanova, Victor Kutsarov, Emil Levi, Alexandra Genova, Rosa Vroom, Hans Noldus, Kiril Bedev, Zdenek Vaclav, Miroslav Slavchev, Silvia Terzieva, Rosen Tzonev, Vera Staevska, Katerina Gudzeva, Galin Georgiev, Veselin Durgov, Radoslav Stanchev.

In passing we would like to thank Chris Day for his editorial assistance with the forum.

\section{References}

Bozo L., Heim W., Harnos A., Csorgo T. 2016 Can we explain vagrancy in Europe with the autumn migration phenology of Siberian warbler species in East Russia? Ornis Hungarica 24 (1): 150-171.

Cramp S., Harris A., Lewington I. 1992 Handbook of the Birds of Europe, the Middle East and North 
Africa: The Birds of the Western Palearctic. 735 pp.

De Juana E. 2008 Where do Pallas's and Yellowbrowed Warblers (Phylloscopus proregulus, Ph. inornatus) go after visiting Northwest Europe in autumn? An Iberian perspective. Ardeola 55 (2): 179-192.

Dimitrov D., Ilieva M., Ivanova K., Brlik V., Zehtindjiev P. 2018 Detecting local transmission of avian malaria and related haemosporidian parasites (Apicomlexa, Haemosporida) at a Special Protection Area of Natura 2000 network. Parasitology Research 117 (7): 2187-2199.

Dontschev S. 1967 Red Phalarope - Phalaropus fulicarius (Linnaeus, 1758) - new species for the Bulgarian ornithofauna. Izvestiya na Zoologicheskia institut s muzey 16: 23-28.

Handrinos G., Akriotis T. 1997 The Birds of Greece. Christofer Helm A \& C. Black Publishers Ltd, 336 pp.

Harrop A. 2007 Eastern promise: the arrival of fareastern passerine vagrants in autumn. British Birds 100: 105-111.

Ignatov A., Mitev D., Berkelder R., Van der Poel P. 2015 Isabelline Shrike Lanius isabellinus: A new species to the Bulgarian avifauna. Acrocephalus 36 (164/165): 79-82.

Ivanov B. 2011 Fauna of Bulgaria. Vol.30 Aves - part III. Bulgarian Academy of Sciences, Sofia, 401 pp. (In Bulgarian)

Ivanov B., Iankov P., Profirov L., Georgiev D., Dimitrov M. 2009 List of the Birds Recorded in Bulgaria. Acta Zoologica Bulgarica 61 (1): 3-26.

Ivanov B., Iankov P., Profirov L., Georgiev D., Dimitrov M. 2015 List of the birds recorded in Bulgaria (Bulgarian List) towards 31 December 2014. https://doi.org/10.13140/RG.2.1.4163.7204

Ivanov B., Iankov P., Profirov L., Georgiev D., Dimitrov M. 2021 Bulgarian National Rarities Committee Report No. 1. https://www.researchgate.net/publication/ 349140726_Bulgarian_National_Rarities Committee_Report_No_1 (Accessed 4 April 2021)
Keller V., Herrando S., Vorisek P., Franch M., Kipson M., Milanesi P., Marti D., Anton M., Klvanova A., Kalyakin M.V., Bauer H.G., Foppen R. 2020 European Breeding Bird Atlas 2: Distribution, Abundance and Change. EBCC \& Lynx Editions, Barcelona, $967 \mathrm{pp}$.

Kyuchukov D. 1997 The Birds of the City. Forest 2: 20.

Martin V., Pochelon A. 2008 Pitulice întunecată (Phylloscopus fuscatus).

https://rombird.ro/ro/obd/2578/

index? or $=0 \&$ ord $=\mathrm{desc} \& \mathrm{sel}=\& \mathrm{dt}=\& \mathrm{df}=\& \mathrm{src}=$ fuscatus $\&$ from $=0 \&$ fromt $=$ fooldal $\&$ fromid $=0$ (Accessed 29 May 2017)

Marton A. 2020 Chituc Ringing Camp Report, 2014-2019. Technical Report. Asociația pentru Protecția Păsărilor și a Naturii Grupul Milvus, Târgu Mureș,78 pp.

Mitev D., Welsch J. 2011 Charadrius mongolus. http:// www.bunarco.org/bg/news-view/6.html.

Nankinov D. 2009 Investigations on the ornithofauna of Bulgaria. ETO Ltd, Sofia, 408 pp. (In Bulgarian)

Nankinov D., Popov K., Byskov F. 2005 Zweiter Nachweis eines Gelbbrauenlaubsängers Phylloscopus inornatus in Bulgarien. Ornithologische Mitteilungen 57 (12): 417-420.

Reeber S., Frémont J.Y., Flitti A., Le Cin A. 2008 Les oiseaux rares en France en 2006-2007. 25 e rapport du Comité d'Homologation National. Ornithos 15 (5): 313-355.

Simeonov P. 2013 Serinus pussilus. http:// www.bunarco.org/bg/news-view/11.html.

Simeonov P. 2015 Phylloscopus proregulus. http:// www.bunarco.org/bg/news-view/19.html.

Van den Berg A., Bosman C. 1999 Rare birds of the Netherlands. Haarlem, 397 pp.

Williamson K. 1983 Identification for ringers. 2 The Genus Phylloscopus. BTO. Maund \& Irwine Ltd, Tring, Herts, 88 pp. 